\title{
Pengaruh modifikasi lift camshaft dengan bahan bakar pertalite dan pertamax terhadap kinerja mesin $110 \mathrm{cc}$
}

\author{
Wahyu Nur Achmadin ${ }^{1 *}$, Indah Noor Dwi Kusuma Dewi², Djoko Wahyudi ${ }^{2}$ \\ ${ }^{1}$ Fakultas Sains dan Teknologi, Universitas PGRI Argopuro Jember \\ Jl. Jawa No.10, Tegal Boto Lor, Sumbersari, Jember, Jawa Timur, Indonesia \\ 2Jurusan Teknik Mesin, Fakultas Teknik, Universitas Panca Marga Probolinggo \\ Jl. Yos Sudarso, No. 107, Pabean, Dringu, Probolinggo, Jawa Timur, Indonesia \\ *Corresponding author: wahyu.achmadin@gmail.com
}

\begin{abstract}
Modification of the camshaft lift with pertalite and pertamax fuel has been carried out. This study aims to determine the effect on engine performance, namely a change in lift of $1 \mathrm{~mm}$ is able to maximize performance to be better than the standard. In this study using a 110 cc motorcycle engine with pertalite and pertamax fuels to show a comparison of modifications to the standard. The results obtained are the modified 1mm lift camshaft with Pertamax fuel produces maximum power and torque compared to the standard camshaft, with values of $13.33 \mathrm{hp}$ and $13.38 \mathrm{Nm}$, respectively. The highest increase in power and torque on pertalite fuel is found at $7000 \mathrm{rpm}$ which can increase performance by $7.4 \%$ and $7.2 \%$, respectively, from the standard camshaft. Meanwhile, the highest increase in power on Pertamax fuel was obtained at $5500 \mathrm{rpm}$ rotation with a value of $12.1 \%$ while the highest torque increase in Pertamax fuel was obtained at 8000 rpm rotation with a value of $11.9 \%$.
\end{abstract}

Keywords: camshaft, power, lift, torque, and enhancement

\begin{abstract}
Abstrak
Modifikasi lift camshaft dengan bahan bakar pertalite dan pertamax telah dilakukan. Penelitian ini bertujuan untuk mengetahui pengaruh terhadap kinerja mesin yaitu perubahan lift sebesar $1 \mathrm{~mm}$ mampu memaksimalkan kinerja menjadi lebih baik dari yang standar. Dalam penelitian ini menggunakan mesin sepeda motor 110cc dengan bahan bakar pertalite dan pertamax untuk menampilkan perbandingan modifikasi dengan standar. Hasil yang diperoleh adalah camshaft modifikasi lift $1 \mathrm{~mm}$ dengan bahan bakar pertamax menghasilkan daya dan torsi maksimal dibanding camshaft standar, dengan nilai masing-masing sebesar $13,33 \mathrm{hp}$ dan 13,38 $\mathrm{Nm}$. Peningkatan daya dan torsi tertinggi pada bahan bakar pertalite terdapat pada putaran $7000 \mathrm{rpm}$ yang mampu meningkatkan kinerja masing-masing sebesar $7,4 \%$ dan 7,2 \% dari camshaft standar. Sementara itu, peningkatan daya tertinggi pada bahan bakar pertamax diperoleh pada putaran $5500 \mathrm{rpm}$ dengan nilai sebesar 12,1\% sedangkan peningkatan torsi tertinggi pada bahan bakar pertamax diperoleh pada putaran $8000 \mathrm{rpm}$ dengan nilai sebesar $11,9 \%$.
\end{abstract}

Kata kunci: camshaft, daya, lift, torsi, dan peningkatan

\section{Pendahuluan}

Keilmuan dalam bidang teknologi menjadikan dasar atas pencapaian tingkat kepuasan dan kenyamanan seseorang. Salah satunya dalam sektor otomotif di saat ini yaitu kendaraan bermotor. Tercatat oleh Badan Pusat Statistik bahwa pada tahun 2018 terdapat 120 juta unit kendaraan sepeda motor di Indonesia [1]. Terlihat bahwa pemanfaatan ilmu pengetahuan dan teknologi memiliki peningkatan atas keinginan masyarakat kepada kendaraan bermotor

Namun, dikarenakan tingkat kepuasan yang dirasa masih kurang dari industri motor, menjadikan rekayasa pada 
bagian otomotif sangatlah diperlukan guna meningkatkan kinerja mesin yang lebih baik lagi dengan cara mengubah spesifikasi komponen pada mesin.

Salah satu cara untuk menghasilkan performa mesin menjadi lebih baik adalah dengan melakukan pengaturan aliran bahan bakar (sumber tenaga) yang masuk serta gas buang (residu) yang keluar dari ruang bakar pada mesin oleh durasi dan lift dari camshaft [2].

Camshaft atau disebut dengan noken as, merupakan komponen yang memiliki operasi yang mampu menggerakkan katup (valve) dengan cara mendrongnya dengan dua tonjolan (lift) [3].

Adapun dua jenis katup yang diketahui pada motor empat langkah, yaitu katup serap/masukan (intake valve) dan katup lepas/buang (exhaust valve). Fungsi dari katup serap ini adalah untuk mengontrol pergerakan udara tercampur dan sumber energi bahan bakar yang kemudian masuk ke dalam silinder mesin, sedangkan katup lepas/buang memiliki fungsi untuk mengontrol pergerakan gas buang yang akan dikeluarkan dari silinder mesin[2-4]. Timing chain memiliki peranan penting yaitu sebagai sistem penggerak dari noken as dengan poros engkol sebagai penghubung antara keduanya [4].

Seperti yang telah dipaparkan di atas, selain camshaft merupakan faktor utama pada unjuk kerja mesin, camshaft memiliki peranan penting lain, diantaranya mampu menentukan durasi operasi saat proses pembukaan pada katup, pengaturan lama durasi operasi pembukaan katup serta terjadinya proses salip antar lap (everlap) dalam katup serap/hisap dan katup lepas/buang $[3,4]$.

Beberapa peneliti telah banyak mengembangkan kinerja camshaft dengan memodifikasi bagian camshaft dalam perancangan mesin poles [5], perubahan sudut [3], penambahan roller rocker arm [2], durasi camshaft [6-9], emisi gas buang [10], kontur [11], profil [12], diameter base circle [13], manufaktur hidroforming [14], dan Lobe Separation Angle [15].

Modifikasi lift pada camshaft dengan bahan bakar yang berbeda diharapkan mampu membandingkan serta meningkatkan performa mesin sehingga dapat memberikan tenaga yang lebih besar kepada putaran mesin saat digunakan. Berdasar dari argumen di atas, maka perlu dilakukan analisis mengenai pengaruh perubahan lift yang terjadi pada kinerja mesin.

\section{Tinjauan Pustaka}

Camshaft merupakan komponen yang digunakan dalam mesin torak untuk menjalankan katup berupa batangan silinder. Saat bahan bakar memasuki ruang silinder setelah bahan bakar tercampur dengan udara pada bagian kaburator atau throttlebody. Kemudian bahan bakar masuk ke dalam ruang silinder yang dikendalikan oleh katup hisap dan katup buang dengan poros engkol sebagai penggeraknya. Komponen ini membuka dengan menekannya, atau dengan mekanisme bantuan lainnya ketika mereka berputar. Hubungan antara perputaran camshaft dengan perputaran poros engkol sangat penting.

Pada mekanisme ini, camshaft berputar satu kali untuk menggerakkan katup hisap dan katup buang setiap dua kali berputarnya poros engkol.

Pada umumnya bahan camshaft terbuat dari besi yang kemudian dilapisi dengan chrom. Pada bagian permukaan dilakukan proses pengerasan (hardening) yang dimaksudkan untuk menambah ketahanan besi terhadap proses aus pada saat bergesekan dengan rocker arm. Oleh karena itu bahan camshaft seharusnya memiliki nilai ketahanan yang tinggi terhadap gesekan [5].

Camshaft dirancang berdasarkan 4 hal [5]:

1. Sudut durasi, waktu pada saat membuka dan menutup katup dalam 1 siklus kerja yang dihitung pada perubahan posisi poros engkol yang 
biasanya dinyatakan dalam satuan derajat.

2. Lift, tinggi angkatan pada katup mulai saat katup tertutup sempurna sampai katup terbuka sempurna. Selisih dari angkatan tersebut dinamakan lift katup.

3. Profil, bentuk dasar dari camshaft.

4. Lobe Separation Angle (LSA), jarak titik puncak tonjolan antara cam in dan cam ex yang diterjemahkan dalam bentuk derajat poros engkol.

Torsi adalah gaya tekan putar pada bagian yang berputar atau dapat diterjemahkan sebagai ukuran kemampuan mesin untuk melakukan kerja. Adapun rumus torsi sebagai berikut :

$$
\mathrm{T}=\mathrm{F} \times \mathrm{l}
$$

Keterangan :

$\mathrm{T}$ : Torsi benda yang berputar $(\mathrm{Nm})$

F : Gaya $(N)$

1 : Jarak benda ke pusat rotasi $(m)$

Daya dihasilkan dari sistem pembakaran pada silinder. Daya sendiri memiliki pengertian besarnya kerja tiap satuan waktu. Daya pada kendaraan bermotor dapat diukur dengan menggunakan rumus [3]:

$$
\mathrm{P}=\frac{2 \pi(\mathrm{n} \cdot \mathrm{T})}{60}
$$

Keterangan:

$$
\begin{aligned}
& \mathrm{P}: \text { Daya (watt) } \\
& \mathrm{n}: \text { Putaran }(1 / \text { sekon }) \\
& \mathrm{T}: \text { Torsi }(\mathrm{Nm})
\end{aligned}
$$

Adapun untuk menghitung peningkatan kinerja dalam rekayasa teknik antara camshaft standar dengan camshaft modifikasi digunakan perhitungan efisiensi. Adapun rumus yang digunakan untuk perhitungan peningkatan daya menggunakan rumus :

$\% P=\frac{P_{\text {modify }}-P_{\text {standar }}}{P_{\text {standar }}} \times 100 \%$

Sedangkan untuk menghitung peningkatan torsi mesin digunakan rumus:
$\% T=\frac{T_{\text {modify }}-T_{\text {standar }}}{T_{\text {standar }}} \times 100 \%$

\section{Metode Penelitian}

\section{Prosedur Penelitian}

Adapun runtutan pelaksanaaan dalam penelitian ini seperti yang tertera pada Gambar 1.

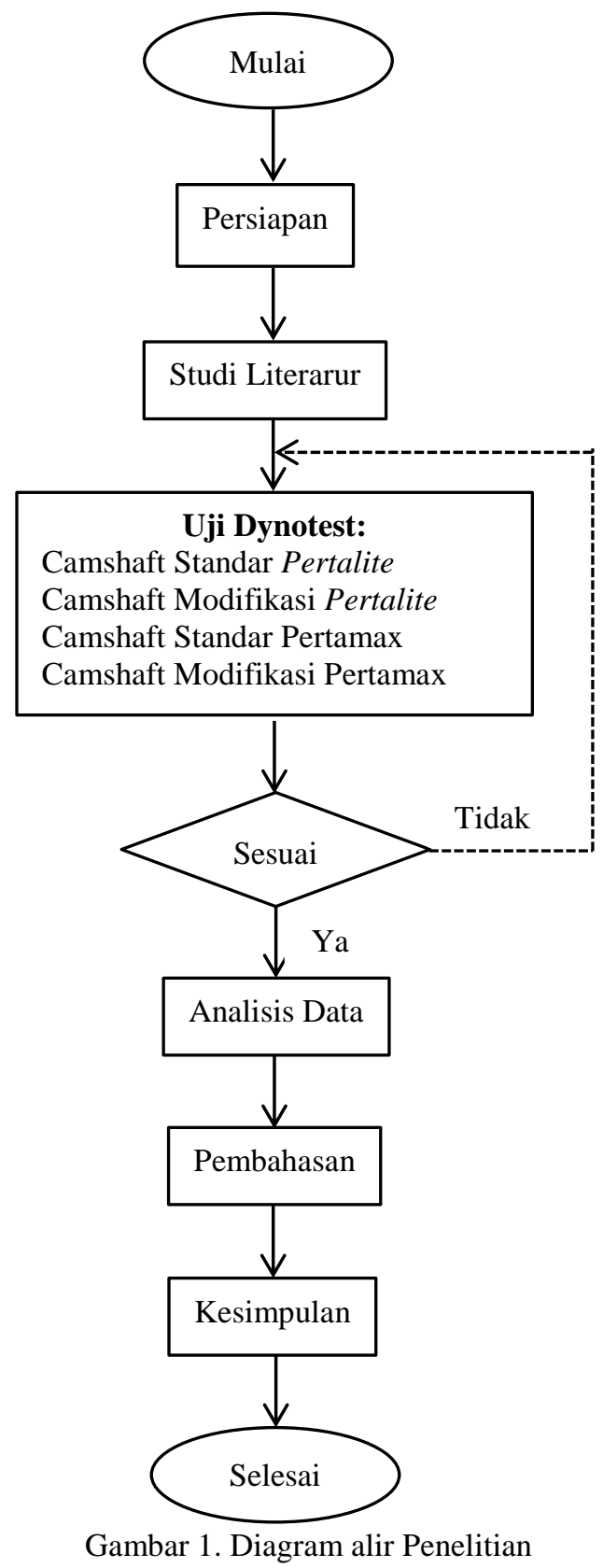

\section{Variabel penelitian}

Pada penelitian ini menggunakan tiga variabel, yaitu : 
1. Variabel bebas

Variabel bebas adalah variabel dengan besaran yang telah ditentukan sebelum dilaksanakan penelitian dan tidak mempengaruhi variabel lainnya. Variabel bebas dalam penelitian ini adalah tinggi lift sebesar $1 \mathrm{~mm}$.

2. Variabel terikat

Variabel terikat adalah variabel yang besarannya ditentukan setelah penelitian dan didapatkan dari variabel bebas. Dalam penelitian ini variabel terikatnya adalah daya, torsi, peningkatan daya, peningkatan torsi.

3. Variabel terkontrol

Variabel terkontrol adalah variabel yang dibuat tetap selama penelitian berlangsung. Pada penelitian ini variabel terkontrolnya adalah tipe sepeda motor yang digunakan yaitu 110cc dan bahan bakar yang digunakan pertalite serta pertamax.

\section{Alat dan Bahan}

1. Satu unit sepeda motor Honda Revo 110cc

2. Camshaft standar dan camshaft modifikasi lift $1 \mathrm{~mm}$

3. Dynamometer

4. Kunci tools set

5. Dial indikator dan busur derjat

6. Pertalite dan pertamax

7. Mesin modifikasi camshaft

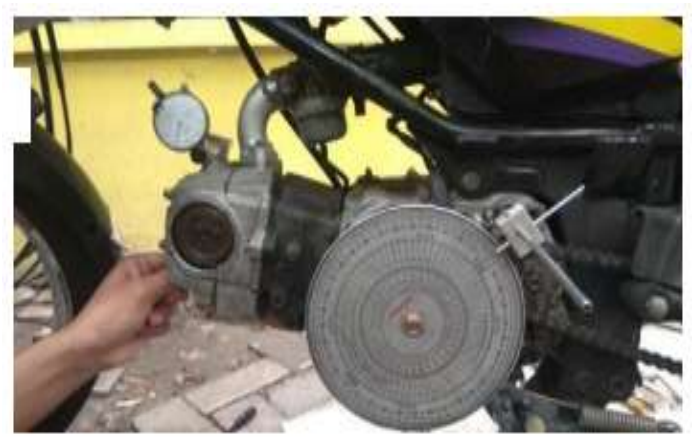

Gambar 2. Dial indikator

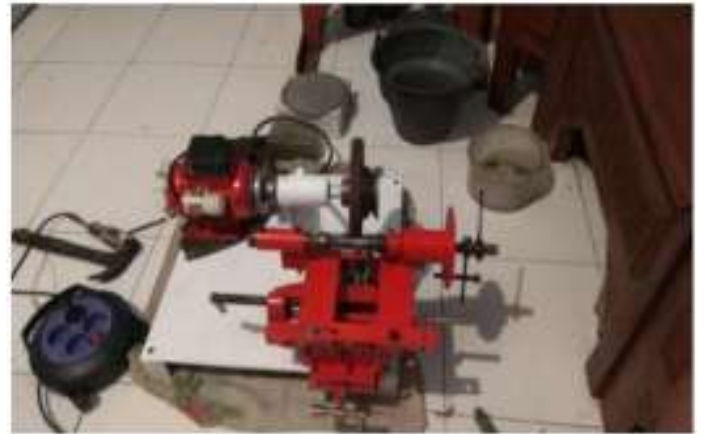

Gambar 3. Mesin modifikasi camshaft

\section{Hasil dan Pembahasan}

Uji dynotest dilakukan untuk mengetahui seberapa maksimal daya maupun torsi pada camshaft yang telah dilakukan modifikasi, grafik dynotest ditampilkan pada Gambar 4.

Hasil yang didapat dari uji dynotest ini kemudian dibandingkan dengan data lainnya.

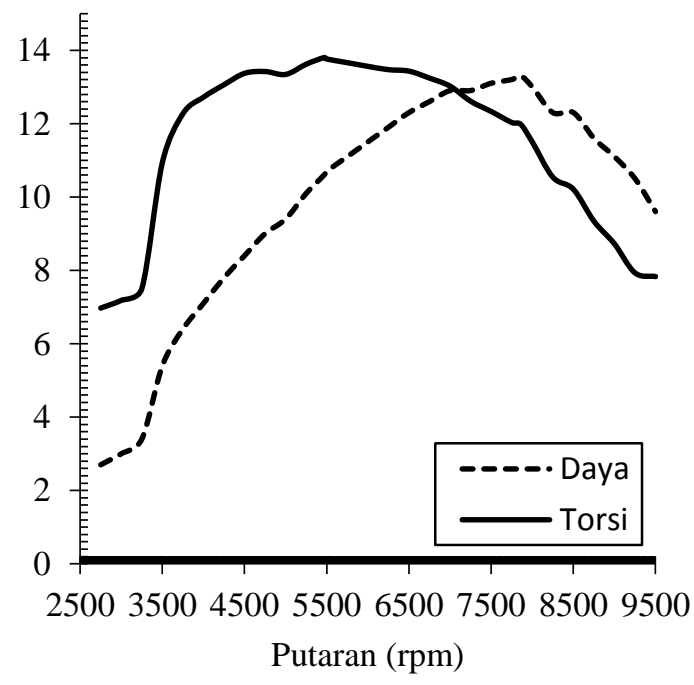

Gambar 4. Hasil dynotest camshaft modifikasi dengan bahan bakar pertamax

Tabel 1 merupakan tabel hasil perbandingan daya antara camshaft standar dengan camshaft modifikasi. Terlihat pada tabel 1 bahwa camshaft modifikasi mampu memberikan peningkatan pada daya mesin pada masing-masing bahan bakar yang digunakan. Kemudian perbandingan torsi pada masing-masing camshaft tersebut ditampilkan pada Tabel 2. 
Tabel 1. Hasil perbandingan daya pada uji dynotest

\begin{tabular}{lcccc}
\hline \multirow{2}{*}{ Camshaft } & \multicolumn{2}{c}{ Pertalite } & \multicolumn{2}{c}{ Pertamax } \\
& $\begin{array}{l}\text { Putaran } \\
(\text { rpm })\end{array}$ & $\begin{array}{c}\text { Daya } \\
(H P)\end{array}$ & $\begin{array}{c}\text { Putaran } \\
(\text { rpm })\end{array}$ & $\begin{array}{c}\text { Daya } \\
(\text { HP })\end{array}$ \\
\hline Standar & 8137 & 12,4 & 7336 & 12,1 \\
Modifikasi & 8103 & 12,9 & 7850 & 13,3 \\
\hline
\end{tabular}

Tabel 2 memberikan perbandingan yang signifikan antara camshaft standar dengan camshaft modifikasi. Dari tabel tersebut, terjadi peningkatan torsi pada camshaft modifikasi di masing-masing bahan bakar yang digunakan pada mesin.

Tabel 2. Hasil perbandingan torsi pada uji dynotest

\begin{tabular}{lcccc}
\hline \multirow{2}{*}{ Camshaft } & \multicolumn{2}{c}{ Pertalite } & \multicolumn{2}{c}{ Pertamax } \\
& $\begin{array}{c}\text { Putaran } \\
(\text { rpm })\end{array}$ & $\begin{array}{c}\text { Torsi } \\
(\mathrm{Nm})\end{array}$ & $\begin{array}{c}\text { Putaran } \\
(\text { rpm })\end{array}$ & $\begin{array}{c}\text { Torsi } \\
(\mathrm{Nm})\end{array}$ \\
\hline Standar & 6826 & 11,7 & 6186 & 12,99 \\
Modifikasi & 7148 & 12,35 & 5468 & 13,8 \\
\hline
\end{tabular}

Untuk mengetahui seberapa jauh perbandingan kinerja antara camshaft standar dan camshaft modifikasi, maka masing-masing camshaft dibandingkan dengan putaran yang tetap. Dalam hal ini putaran yang ditetapkan untuk perbandingan adalah putaran $5500 \mathrm{rpm}$ hingga $8000 \mathrm{rpm}$ dengan rentang putaran 500 rpm. Penentuan putaran ini dikarenakan, kondisi kinerja maksimal mesin terdapat pada putaran tersebut yang menandakan pemasukan sumber energi bahan bakar pada mesin lebih cepat sehingga daya yang diperoleh menjadi lebih tinggi akibat pemasukan tersebut [2].

Terlihat pada Gambar 5 bahwa hasil banding antara komponen standar dengan komponen modifikasi terdapat perbedaan yang signifikan. Adapun pada bahan bakar pertalite, mesin yang menggunakan camshaft modifikasi (garis hitam) memperoleh nilai daya mesin lebih besar dibandingkan mesin yang menggunakan camshaft standar (garis putus-putus hitam).

Hal ini dikarenakan lebih kecilnya ukuran Lobe Separation Angle (LSA) pada camshaft yang sudah dilakukan rekayasa (modifikasi) dibandingkan dengan camshaft standar menjadikan lebih cepatnya pembukaan katup hisap pada camshaft yang sudah dimodifikasi sebelum Titik Mati Atas dan tertutup pada saat telah mencapai Titik Mati Atas pada katup lepas.

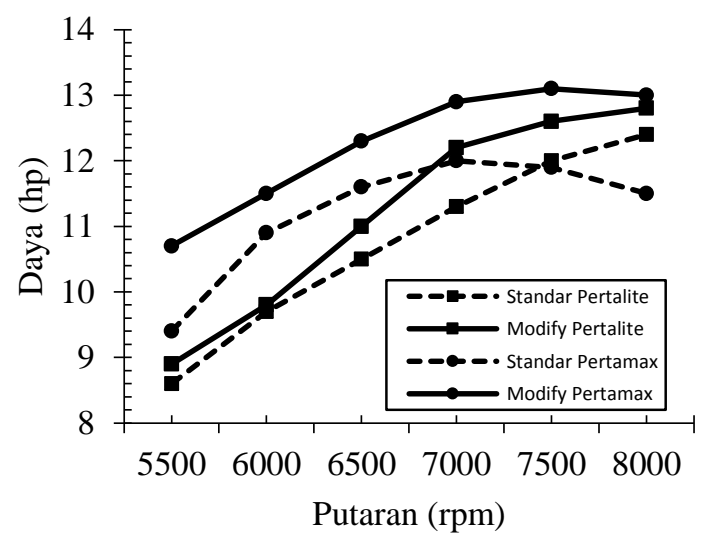

Gambar 5. Perbandingan daya camshaft standar dan modifikasi dengan bahan bakar pertalite dan pertamax

Berbeda dengan camshaft pada standar yang memiliki proses pembukaan katup hisap dan proses penutupan katup lepas setelah mencapai Titik Mati Atas.

Hal inilah yang menyebabkan kenaikan daya mesin dari 5500 rpm sampai 8000 rpm masih berlanjut, dikarenakan semakin cepat pemasukan sumber energi bahan bakar pada proses tersebut maka terdinya daya mesin yang menjadi tinggi [2].

Kondisi ini pun terjadi pada bahan bakar pertamax, dari putaran $5500 \mathrm{rpm}$ sampai putaran $7000 \mathrm{rpm}$ (Gambar 5). Mesin yang menggunakan camshaft modifikasi (garis merah) memperoleh nilai daya mesin lebih besar dibandingkan mesin yang menggunakan camshaft standar (garis putus-putus merah).

Pada camshaft standar dengan bahan bakar pertamax terjadi penurunan daya di putaran 7000 rpm, sedangkan pada camshaft modifikasi dengan bahan bakar pertamax terjadi penurunan daya di putaran $7500 \mathrm{rpm}$.

Hal ini dikarenakan camshaft yang dilakukan rekayasa (modifikasi) memiliki 
profil katup-katup yang lebih tinggi dibandingkan dengan katup-katup pada camshaft standar. Hal ini menyebabkan jumlah berbagai bahan bakar (campuran bahan bakar) masuk lebih banyak ke dalam mesin sehingga tekanan kompresi yang diperoleh menjadi lebih tinggi daripada camshaft standar[2]. Hal ini membuktikan bahwa modifikasi lift mampu meningkatkan daya mesin.

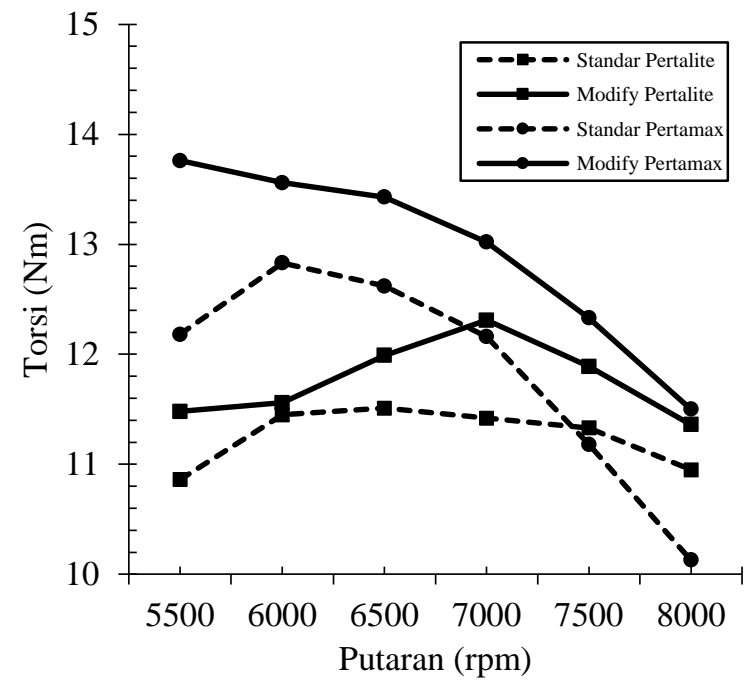

Gambar 6. Perbandingan torsi camshaft standar dan modifikasi dengan bahan bakar oktan pertalite dan pertamax

Hasil banding nilai torsi didapatkan melalui uji dynotestt kemudian digabung seperti pada Gambar 6.

Pada Gambar 6 dapat terlihat bahwa torsi pada camshaft standar lebih kecil dibandingkan dengan torsi camshaft modifikasi. Hal ini dikarenakan proses terbukanya katup lepas camshaft modifikasi terjadi pada saat sebelum Titik Mati Bawah (TMB), sehingga tekanan akibat pembakaran sumber energi pada ruang bakar menjadi berkurang pada saat piston belum mencapai Titik Mati Bawah [2].

Adapun terjadinya kenaikan torsi pada camshaft standar dengan bahan bakar pertamax di putaran 5500 rpm sampai 6000 rpm dikarenakan terjadinya pengurangan gesekan pada putaran mesin, meskipun mencapai putaran yang tinggi sehingga mampu menunjukkan kinerja mesin secara optimal. Pengurangan gesekan dapat terjadi dikarenakan adanya komponen lain yang memengaruhi putaran mesin [2]. Hal serupa juga terlihat pada camshaft modifikasi dengan bahan bakar pertalite di putaran $5500 \mathrm{rpm}$ sampai putaran $7000 \mathrm{rpm}$.

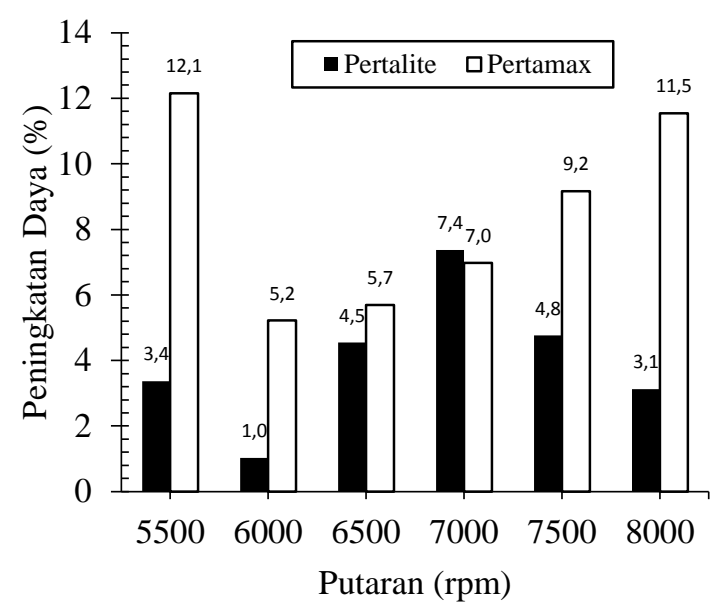

Gambar 7. Peningkatan daya camshaft standar dan modifikasi dengan bahan bakar pertalite dan pertamax

Setelah mengetahui perbandingan antara camshaft standar dan camshaft modifikasi, maka dapat dihitung nilai peningkatan (efisiensi) dari perbandingan ini. Berikut perbadingan peningkatan daya yang ditampilkan pada Gambar 7.

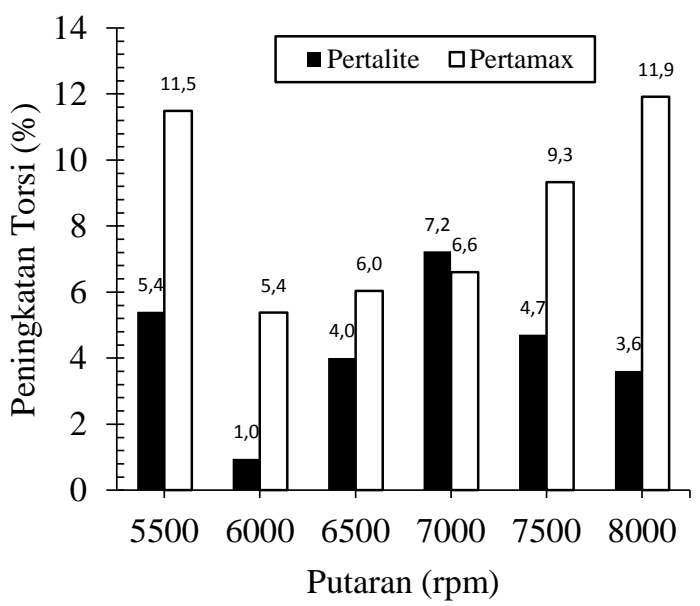

Gambar 8. Peningkatan torsi camshaft standar dan modifikasi dengan bahan bakar pertalite dan pertamax

Terlihat pada Gambar 7 bahwa pada bahan bakar pertalite peningkatan daya terbesar diperoleh pada putaran $7000 \mathrm{rpm}$ dengan meningkat sebesar 7,4\%.sedangkan 
peningkatan daya pada bahan bakar pertamax terjadi pada putaran $5500 \mathrm{rpm}$ yaitu meningkat sebesar $12,1 \%$.

Adapun Gambar 8 menampilkan bahwa peningkatan torsi terbesar pada bahan bakar pertalite diperoleh pada putaran $7000 \mathrm{rpm}$ dengan peningkatan torsi sebesar 7,2 \%, sedangkan peningkatan torsi terbesar pada bahan bakar pertamax diperoleh pada putaran $8000 \mathrm{rpm}$ dengan peningkatan torsi sebesar $11,9 \%$.

\section{Kesimpulan}

Berdasarkan hasil penelitian uji camshaft standar dan camshaft modifikasi pada bahan bakar pertalite dan pertamax diperoleh hasil bahwa camshaft modifikasi lift $1 \mathrm{~mm}$ dengan bahan bakar pertamax menghasilkan daya dan torsi maksimal dibanding camshaft standar, dengan nilai masing-masing sebesar 13,33 HP dan 13,38 Nm. Adapun peningkatan daya dan torsi tertinggi pada bahan bakar pertalite terdapat pada putaran 7000 rpm yang mampu meningkatkan kinerja masingmasing sebesar 7,4 \% dan 7,2 \% dari camshaft standar. Sementara itu, peningkatan daya tertinggi pada bahan bakar pertamax diperoleh pada putaran 5500 rpm dengan nilai sebesar 12,1\% sedangkan peningkatan torsi tertinggi pada bahan bakar pertamax diperoleh pada putaran 8000 rpm dengan nilai sebesar 11,9 $\%$.

\section{Referensi}

[1] Prasetyo I T, Sudrajad A and Yusuf Y 2020 Modifikasi Durasi Camshaft Untuk meningkatkan Performa Mesin Satu Silinder 115 cc Media Mesin Maj. Tek. Mesin 21 84-90

[2] Muhajir H K, Susastriawan A A ., Aziz M H N and Rompas P 2018 Pengaruh Variasi Tinggi Lift, Lobe Separation Angle Camshaft, dan Roller Rocker Arm Terhadap Unjuk Kerja Motor Bensin Empat Langkah Front. J. SAINS DAN Teknol. 1 7-16

[3] Yuono L D and Budiyanto E 2020
Pengaruh perubahan sudut camshaft terhadap performa mesin sepeda motor sebagai upaya efisiensi energi Turbo J. Progr. Stud. Tek. Mesin 9 78-86

[4] Yamagata H 2005 The camshaft The Science and Technology of Materials in Automotive Engines (Elsevier) pp 110-31

[5] Sawaludin L, Murila S, Ode L and Solihin D 2017 Perancangan Mesin Poles Serba Guna (Modifikasi Camshaft/Noken As) ENTHALPY J. Ilm. Mhs. Tek. Mesin 2 1-8

[6] Nagaya K, Kobayashi $\mathrm{H}$ and Koike K 2006 Valve timing and valve lift control mechanism for engines Mechatronics 16 121-9

[7] Kristianto D 2017 Pengaruh Perubahan Durasi Camshaft Terhadap Performance Mesin FD 110cc J. Tek. Mesin 54-7

[8] Putra F S, Sanata A and Muttaqin A Z 2013 Pengaruh Variasi Durasi Camshaft Terhadap Unjuk Kerja Motor Bakar 4 Langkah J. ROTOR 6 27-30

[9] Hidayah M K, Bugis $\mathrm{H}$ and Rohman N 2012 Analisis Torsi dan Daya Akibat Pemotongan Ramp Poros Bubungan (Camshaft) pada Sepeda Motor Suzuki Shodun 125 SP Tahun 2005 J. Nosel 1 (2)

[10] Darmawangsa F I 2016 Analisis Pengaruh Penambahan Durasi Camshaft Terhadap Unjuk Kerja dan Emisi Gas Buang Pada Engine Sinjai 650cc J. Tek. ITS 5

[11] Choirul Anam M 2018 Pengaruh Variasi Perubahan Kontur Camshaft Terhadap Unjuk Kerja Pada Honda Megapro 160 D Advanced $J$. Pendidik. Tek. Mesin 7 85-92

[12] Andrew Wijaya S Pengaruh Perubahan Profil Camshaft Terhadap Unjuk Kerja Motor Satria F150 CC DOHC J. Tek. Mesin Petra 1-5

[13] Ghaly M S, Agus Winoko Y, Mesin 
T and Malang P N 2019 Analisis Perubahan Diameter Base Circle Camshaft Terhadap Daya Dan Torsi Pada Sepeda Motor J. Flywheel 10 7-12

[14] Ma J, Yang L, Liu J, Chen Z and He Y 2021 Evaluating the quality of assembled camshafts under pulsating hydroforming J. Manuf. Process. 61 69-82

[15] Susilo A 2013 Pengaruh Besar LSA (Lobe Separation Angle) Pada Camshaft Terhadap Unjuk Kerja Mesin Sepeda Motor 4 Langkah Jtm $1245-50$ 